\title{
КОНСУЛЬТАЦИИ
}

\section{ZONE OF PROXIMAL DEVELOPMENT AND SCAFFOLDING REQUIRED BY JUNIOR HIGH SCHOOL STUDENTS IN SOLVING MATHEMATICAL PROBLEMS}

\author{
D. P. Utomo' ${ }^{1}$ T. Santoso² \\ University of Muhammadiyah, Malang, Indonesia. \\ E-mail: ${ }^{1}$ dwipriyoutomo2021@gmail.com,dwi_priyo@umm.ac.id; \\ ${ }^{2}$ teguhsantosoumm@gmail.com
}

\begin{abstract}
Introduction. Mathematics comprises grading concepts. It means that one specific concept can be interrelated to another concept, which embodies a continuous process. Mathematics instruction at schools is ordinarily delivered from the easiest to the hardest concepts and requires a considerably deep understanding of each concept. By acquiring the understanding, it is quite certain that students can solve mathematical problems effectively.

Aim. The current research aimed to analyse and describe the Zone of Proximal Development (ZPD) and scaffolding required by junior high school students in mathematical problem-solving. There is also an attempt to describe the actual level of competence possessed by students, and to determine the level of scaffolding needed to develop students' learning competencies.
\end{abstract}

Methodology and research methods. The present research employed a qualitative method within the descriptive approach. The research sample consisted of six students who attended the ninth grade at Muhammadiyah Junior High School 1 in Malang, Indonesia. The participants were grouped based on their mathematical competence levels, i.e. two high-achievers, two average-achievers, and two low-achievers. The data collection technique is done by giving tests, interviews, and observations. As for the teaching material, geometry was chosen as the main theme, covering the topic "Volumes of a Tube and a Ball".

Results. This research revealed that ZPD of the high-achievers was effective to help them solve mathematical problems independently. Conversely, the average- and low-achievers were found to be problematic at solving mathematical problems independently. The teachers must review and restructure the scaffolding strategies, dealing intensively with students who are less competent in solving mathematical problems.

The scientific novelty of the work lies in the fact that previous studies have described efforts to improve the quality of learning through scaffolding (Siyepu S., 2013). This study describes in full the scaffolding process in the classroom: identification of students' actual abilities and potential abilities after implementing instructional scaffolding.

Practical significance. Referring to the results of the research, it is suggested that teachers should be so heedful about their students' ZPD and thus more appropriate scaffolding 
treatments can be applied. In addition, teachers are strongly recommended doing self-training in scaffolding and keeping the instruction for their students to analyse their answers repeatedly to avoid a fallacy in operations. Besides, teachers should prepare their students to be good problem-solvers by exposing them to various exercises. For further studies, it is highly expected that more relevant research should be conducted from different viewpoints, i.e. investigating the effective scaffolding strategies.

Keywords: zone of proximal development, scaffolding, actual competence, potential competency, mathematical problem-solving.

Acknowledgements. This study was supported by the Research and Community Service Institute of University of Muhammadiyah (Malang, Indonesia).

For citation: Utomo D. P., Santoso T. Zone of proximal development and scaffolding required by junior high school students in solving mathematical problems. The Education and Science Journal. 2021; 23 (9): 186-202. DOI: 10.17853/1994-5639-2021-9-186-202

\title{
ЗОНА БЛИЖАЙШЕГО РАЗВИТИЯ И СКАФФОЛДИНГ, НЕОБХОДИМЫЕ ДЛЯ УЧЕНИКОВ СРЕДНЕЙ ШКОЛЫ ПРИ РЕШЕНИИ МАТЕМАТИЧЕСКИХ ЗАДАЧ
}

\author{
Д. П. Утомо1, Т. Сантосо ${ }^{2}$ \\ Университет Мухаммадии, Маланг, Индонезия. \\ E-mail: 1'dwipriyoutomo2021@gmail.com,dwi_priyo@umm.ac.id; \\ 2teguhsantosoumm@gmail.com
}

\begin{abstract}
Аннотация. Введение. Математика включает в себя классификацию понятий. Это означает, что одно конкретное понятие может быть взаимосвязано с другим понятием, и этот процесс непрерывен. Обычно математику в школах изучают от самых простых понятий до самых сложных, что требует глубокого понимания каждого из них. Совершенно очевидно, что, приобретая понимание, обучающиеся могут эффективно решать математические задачи.

Цель. Настоящее исследование направлено на анализ и описание зоны ближайшего развития (ЗБР) и скаффолдинга (педагогической поддержки), необходимых дмя учеников средней школы при решении математических задач. Предпринята попытка описать фактический уровень компетентности, приобретенной школьниками, и определить уровень скаффолдинга, необходимого дмя формирования учебных компетенций

Методология и методы исследования. В данном исследовании используется метод качественного анализа на основе описательного подхода. Объектом являлись шесть учеников девятого класса средней школы Мухаммадия 1 Маланг (Маланг, Индонезия) приняли участие в исследовании. Испытуемые были сгруппированы на основе их уровня математической компетентности: два ученика с высоким уровнем достижений, два - со средним, два - с низким. Данные были собраны с помощью тестирования, собеседования и наблюдения. Что касается учебно-методических материалов, то в качестве основной темы была выбрана геометрия, охватывающая раздел "Объемы цилиндра и шара".
\end{abstract}


Результаты. Данное исследование показало, что обучение учеников с высоким уровнем достижений в ЗБР было эффективным для самостоятельного решения математических задач. И наоборот, у учеников со средним и низким уровнем достижений были обнаружены проблемы при самостоятельном решении математических задач. Учителям необходимо пересматривать и дорабатывать стратегии скаффолдинга, работая в интенсивном режиме со школьниками, которые хуже справцяются с математическими задачами.

Научная новизна исследования заключается в том, что предыдущие работы описывали мишь попытки по повышению качества обучения с помощью скаффолдинга (Siyepu S., 2013). Настоящее исследование полностью описывает процесс скаффолдинга в классе: определение фактических способностей школьников и выявление потенциальных способностей после применения технологии скаффолдинга.

Практическая значимость. Результаты исследования предполагают, что учителя должны быть более внимательными и, следовательно, применять более подходящие стратегии скаффолдинга при обучении детей в средней школе. Кроме того, учителям настоятельно рекомендуется самосовершенствоваться и заниматься самообразованием в области реализации педагогической технологии скаффолдинга, продолжая обучать своих учеников, чтобы систематически анализировать ответы школьников во избежание ошибок в вычисмениях. Более того, учителя должны подготовить своих учеников хорошо решать различные математические задачи, предлагая им другие варианты упражнений. Для осуществления дальнейших научных изысканий весьма ожидаемо проводить релевантные исследования с различных точек зрения, например, исследовать стратегии эффективного скаффолдинга.

ключевые слова: зона ближайшего развития, скаффолдинг, фактическая компетентность, потенциальная компетентность, решение математических задач.

Благодарности. Данное исследование было поддержано Институтом исследований и общественных работ Университета Мухаммадии (Маланг, Индонезия).

для иитирования: Утомо Д. П., Сантосо Т. Зона ближайшего развития и скаффолдинг, необходимые дмя учеников средней школы при решении математических задач // Образование и наука. 2021. T. 23. № 9. C. 186-202. DOI: 10.17853/1994-5639-2021-9-186-202

\section{Introduction}

Mathematics comprises grading concepts. It means that one specific concept can be interrelated to another concept, which embodies a continuous process. Mathematics instruction at schools is ordinarily delivered from the easiest to the hardest concepts and requires considerably deep understanding on each concept. By acquiring the understanding, it is quite certain that students can solve mathematical problems effectively. As asserted in [1], there are several purposes of mathematics instruction at school intended for the students, namely: 1) learning to respect mathematics; 2) building self-confidence in using mathematics; 3) being a good problem solver; 4) learning to get exposed to mathematical interactions; and 5) learning to make mathematical reasoning. For the sake of aiming for those purposes, teachers' role as a learning facilitator is pivotal. 


\section{Literature Review}

The concept of zone of proximal development (ZPD) was developed by Lev Semenovich Vygotsky during the late 1920s and elaborated progressively until his decease in 1934 [2]. According to Vygotsky, ZPD refers to a gap between actual and potential competence levels, in which the former typifies an independent problem-solving process and the latter epitomises an assisted process that commonly goes along with the supervisory of more competent figures [3]. Additionally, [4] aver that ZPD constitutes a 'spot' where cognitive competence is formed altogether and how the cognitive development is supported. ZPD, moreover, is also marked as the difference that lies on what individuals can do without any assistances and what they can do with particular assistances [5]. Vygotsky has also believed that learning process occurs when children work along with their ZPD since it embodies a space of actual competence level, allowing them to do problem-solving self-reliantly [6]. Vygotsky [7] added that those who could automatically do any tasks at specific cognitive levels and work together with adults would perform tasks at higher level of competence, and the variation of these levels could only be found at children's ZPD.

Teachers, therefore, can make use of ZPD to accommodate any possibilities students can perform without any and with some assistances [5]. Gallimore and Tharp [5] asserted that life-long learning carried out by every individual comprises ZPD that is equitably processed, with the assistances provided by people, and self-reliance that is performed repeatedly for the sake of new capacity development. Further, Vygotsky [5] highlighted that what ZPD presently contributes could determine the actual development level in the future, which means that any of what students can do with some assistances today might help them do the same things independently in some other occasions in the future. Vygotsky [2], additionally, applied collaboration and interpretation procedures as diagnostics for an instructional experiment in an attempt to identify students equipped with higher and lower ZPD. It was noted that ZPD remarked the difference that revealed everything students could do with or without any assistances from adults [6].

The concept of scaffolding was initially introduced by Wood, Bruner, and Ross in 1976 on the basis of the Vygotsky's development theory. The concept was made referential to explaining the roles of adults and numbers of friends to support children's learning and development [7]. According to the Pfister M., Opitz E. M., and Pauli C. [8], scaffolding is a supporting system that concerns on understanding and structure. Wood et al [8] have considered scaffolding as a process that allows children or beginners to solve problems or to complete some 
tasks in order to achieve particular goals exceeding their efforts in the absence of assistances. On top of that, scaffolding treatment is provided by teachers or students who are considered eligible and more competent to assist those (students) who are in troubles. Scaffolding, additionally, should be graded, preceded by providing noteworthy assistances and ended by giving less assistances with the purpose of getting them accustomed to solving problems independently [9]. Scaffolding is also helpful for students who find it difficult to achieve certain expected goals in addition to helping them think critically of how to solve problems, even the most challenging ones $[10,11]$. When children get improved, in terms of skills, due to an ideal support, scaffolding needs to be minimised so as to let them do everything self-reliantly [3, 7]. Referring to [12], scaffolding is worth-doing when students have come to desperation when completing a particular task.

Scaffolding needs explicit attention in order to identify potential strengths and weaknesses during the instructions [13]. That sort of diagnostic action is considered necessary for the beginning of higher level scaffolding. Lipscomb [3] has suggested two major steps to take for scaffolding instructions, namely: 1) instructional plan development aiming at giving students clear directions of what they have known as well as an in-depth understanding on new materials and 2) well-planned execution in which all instructors are to give support to their students in each step of instructional activities. [14] illustrated that scaffolding amidst learning processes could be reinforced by giving feedback, guidelines, instruction, explanation, modelling, and Q\&A sessions. To make scaffolding effective, teachers are to determine the differences that are evident between what students can make with and without any guidance [7].

According to [7], there are several scaffolding principles to follow, namely: 1) maintaining good balance between 'confronting' and 'supporting' students, 2) using proper scaffolding, 3) modelling traits and behaviours that are deemed beneficial (such as doing experiment, avoiding judgment, and raising sense of openness), 4) providing students with good and supportive environment, and 5) responding and giving feedback to students in response to questions and comments they have proposed. [9] has asserted that there are three levels of scaffolding, to name: Level 1 referring to environmental provisions (classroom organisation, artifacts); Level 2 concerning on explaining, reviewing, and restructuring; and Level 3 focusing on developing conceptual thinking. The goals of mathematics instructions are 'well-achieved' when the supports from the competent facilitators are effective.

Problem solving, moreover, is one of primary foundations for mathematics instructions [15]. Referring to [9] problem solving constitutes an 
attempt to overcome difficulties in order to reach all expected goals. More specifically, mathematical problem solving is defined as a process of finding out combination of laws or information acquired in advance as an essential capital to solve mathematical problems [1]. Problem solving plays an essential role in mathematics education due to its nature that can help students think mathematically [16]. Additionally, not only mathematical knowledge, understanding on particular situations conveyed by texts is also necessary for problem-solving since the problems commonly ricochet real-world settings [17].

In mathematical problem-solving, students are required to be able to understand mathematical concepts being learned and to put the concepts into practice [18]. Further, students' problem-solving skill can be identified based on problem-solving steps proposed by [9], such as: 1) understanding questions, 2) drafting procedures of answering the questions, 3) executing the procedures, and 4) reviewing the validity of the procedures taken for answering the questions. Along with the improvement on mathematical problem-solving skill, students' mathematical competence will get improved. For that reason, at the very beginning, teachers are to investigate the levels of students' actual development through mathematical problem-solving activities. Next, proper and precise scaffolding can be included. Accordingly, with all supportive assistance, students can really achieve their potential development. Accomplishment of students' potential development level remarks the success in achieving one of mathematical goals, that students are good at solving problems [1].

On top of that, problem-solving in this current research was referred to any non-routine mathematical problem-solving tasks. In addition, the researchers were responsible for giving scaffolding treatment right after the interview with the students. Next, the researchers provided the students with proper and precise assistances based on their actual development levels. With all supports and guidance, the students received scaffolding treatment. An analysis of the ZPD could be executed by investigating the students' actual and potential development through mathematical problem-solving.

There have been a number of studies discussing ZPD. One carried out by [5] has shown a sociocultural theory of learning that considers ZPD as a possible solution to the development of instructional practices as well as to the suppression of high rates of mathematical failure in South Africa. In addition, another research by [5] has revealed that teachers' roles are not necessarily about giving structured directions to facilitate performance; instead, explorative discussion and social mediation are more recommended to help students control their own learning processes. 
Practically, this current research presented an analysis of ZPD and scaffolding practices to solve mathematical problems. Therefore, the most ultimate purpose was to investigate the students' actual development in mathematical problem-solving. Further, scaffolding was applied to the students in an attempt to help them achieve their potential levels as expected. Eventually, this research was focused on to what extent the students' potential has developed after receiving scaffolding treatment.

\section{Methodology}

\section{Design}

This research employed qualitative design by means of descriptive approach. As the research subjects, six students of IX-A (ninth graders) of SMP Muhammadiyah 1 Malang, Indonesia, were selected. The subjects were grouped based on their mathematical competences, namely: two high-achievers (coded as A1 and A2), two average-achievers (coded as B1 and B2), and two low-achievers (coded as C1 and C2). The data of the students' actual and potential developments were acquired by referring to their answers. The data related to the scaffolding practices were obtained from the observation. To collect all data, test, interview, and observation were used as the instruments. There were two items about geometrics; the first item was given before the treatment of scaffolding, while the second item was given after the treatment of scaffolding. Next, the interview was carried out to examine the validity of the students' answers written on the answer sheet. The results were analysed to find out the students' actual development levels by reflecting on how they performed the steps [19]. The interview was made unstructured in which the questions were flexible. In addition, observation was conducted to collect the data about scaffolding practices. To support the observation, assistive tools were used, such as observational notes and scaffolding indicators based on the theory of [9], proposing three hierarchical levels of scaffolding practices.

The data analysis method was referred to the theory of Miles and Huberman, comprising data reduction, data presentation, and drawing upon conclusion. The pre-test was aimed at identifying the students' actual development levels, supported by the results of interview. In addition, scaffolding was applied if necessary. Scaffolding was applied by considering the results of observation as written in the observation notes. After receiving scaffolding treatment, the students were required to answer a question equivalent to the former question. This procedure was meant to see their potential development levels (Table 1). 


\section{Instrument}

Table 1

Initial Test (Actual Development Test) and Final Test

(Potential Development Test)

\section{Before the scaffolding}

Calculate the volume of a cone below, with $\pi=3.14$.

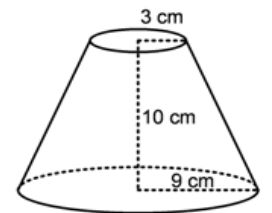

\section{After the scaffolding}

Calculate the volume of a bucket below, with $\pi=3.14$.

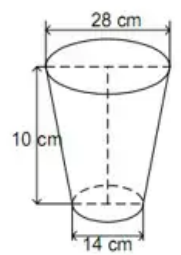

\section{Results}

Actual Development Level, Scaffolding, and Potential Development Level of the High-Achievers

Since A1 and A2 had the same answer, the description was focused to A1's. Referring to the answer, the subjects could answer the question by using necessary concept and procedure independently and it has remarked their actual development level. To prove, see the following answers written by A1 as shown in Figure 1.

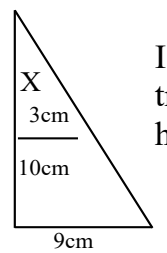

I make a right

triangle to find the

height of the cone

$$
\begin{aligned}
& \frac{x}{3}= \\
& 9 x=3 x+30 \\
& 6 x=30 \\
& X=5
\end{aligned}
$$

$$
\begin{aligned}
\frac{(x+10)}{9} \quad & Y=V_{\text {whole cone }}-V_{\text {little cone }} \\
& =\frac{1}{\mathbf{3}} \times 3,14 \times 9^{2} \times 15-\overline{3} \times 3,14 \times 3^{2} \times 5 \\
= & 3,14 \times 405-3,14 \times 15 \\
= & 1.271,7-47,1 \\
= & 1.224,6
\end{aligned}
$$$$
\text { cone height }=10+5=15 \mathrm{~cm}
$$

So, the volume is $1224.6 \mathrm{~cm}^{3}$

Fig. 1. A1's answer

Referring to Figure 1, the concept and procedure to answer the question were in line with the rubric of the question, conic and congruency concepts, along with a procedure used for comparison and algebraic operation. Besides, the 
finding was also supported by the result of interview with A1, presented below.

$R \quad$ : What kind of plan will you take to answer the second question?

A1 : I'll assume that this is a cone. Then, I try to calculate the volume of the big cone and small cone separately. Finally, I do subtraction on the volume of the big cone by that of the small one.

$R$ : Prior to getting the final result of the volumes from both of the cones, is there anything you need to calculate?

A1 : Yes, all right. It is the height.

$R \quad$ : How will you find out the height?

A1 : Just make a comparison, 3 to 9 and 10 to $\chi$ (while pointing out the answer sheet).

Based on the identified palpability of actual development level, A1 did perform independently without any help. In sum, as the potential development level was detected, A1 was seen potential to continue doing other things with higher level of difficulty, which is in need of other supportive concepts.

\section{Actual Development Level, Scaffolding, and Potential Development Level of the Average-Achievers}

Considering the identical answers of B1 and B2, the description would be referred to B1's as the representative. The following Table 2 shows how B1 answered the question.

Table 2

B1's answer

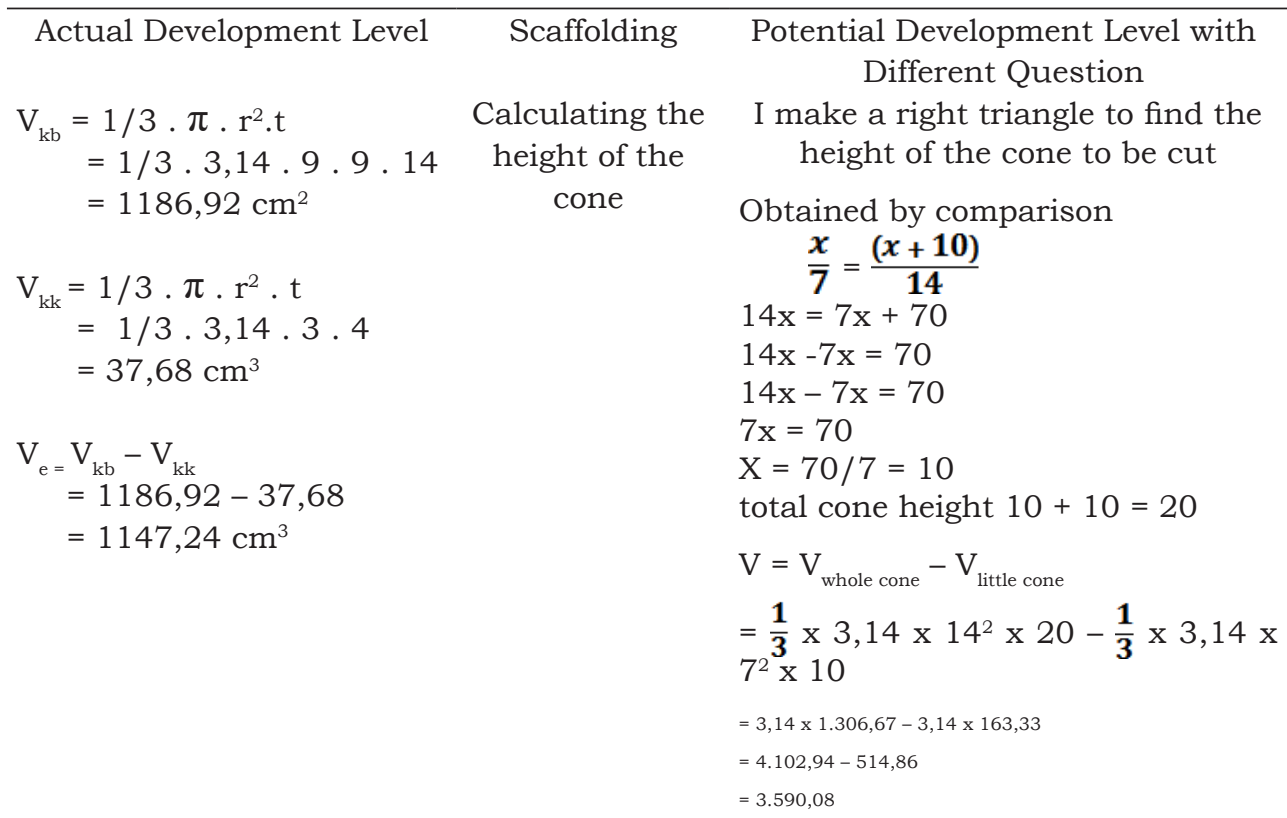

Образование и наука. Том 23, № 9. 2021 / The Education and Science Journal. Vol. 23, № 9. 2021 
Based on B1's answer as shown in Table 2, a mistaken procedure was found. The plan for calculating the bucket's volume was correct, but determining the height of the small cone remained a bit misguided. The finding was supported by the result of interview with B1 as denoted in the following excerpt of interview.

$R \quad$ : How will you answer the second question?

$B 1$ : To my understanding, a bucket resembles a cone. So, I'll start to calculate the volumes of the big and small cones separately, and do a subtraction operation on the volumes.

$R \quad$ : Before searching for the final volume after the subtraction, do you need to calculate anything?

$B 1$ : Yes, the height.

$R \quad:$ How will you calculate the height?

$B 1$ : It can be done through the Pythagorean theorem. Look, this is a special triangle, isn't it? If you see, here is $3 \mathrm{~cm}$, so the second side will be $4 \mathrm{~cm}$, and the hypotenuse is obviously $5 \mathrm{~cm}$.

B1 should have calculated the height by using a congruency concept through comparison procedure. In this case, B1's actual development level was answering the question using a conic concept along with a procedure of algebraic operation independently. In other words, B1 was in need of scaffolding when it came to finding out the height of the cone.

With reference to the observation result, the first procedure was making essential information as clear as possible, stating that there was a right triangle in the cone. Then, the subject was asked to recall the concept of congruency through an interview. Initially, B1 could not recall the information clearly (indicated by the delay in answering the question). After being given an illustration of a perfect right triangle, with the length in each of the sides, B1 started to understand how to find out the height of the cone, performed by making comparison of the parallel sides.

With the guidance, B1 started to make a correction on the committed errors independently. B1 was also asked to answer the second question. Based on the answer to the second question, B1's potential development level was apparent. After having the scaffolding, B1could answer the question using a correct concept and procedure.

Actual Development Level, Scaffolding, and Potential Development Level of the Low-Achievers

$\mathrm{C} 1$ and $\mathrm{C} 2$ had different answers. Accordingly, both will be elaborated in this section. The following Table 3 presents C1's work. 
Table 3

C1's answer

\begin{tabular}{|c|c|c|}
\hline Actual Development Level & Scaffolding & $\begin{array}{l}\text { Potential Development Level } \\
\text { with Different Question }\end{array}$ \\
\hline $\begin{aligned} V_{k b} & =\frac{1}{3} \pi r^{2} t \\
& =\frac{1}{3} \cdot 3 \cdot 14 \cdot g^{3} \cdot 9 \cdot 10 \\
& =897,8 \\
V_{k l e} & =\frac{1}{3} \cdot \pi \cdot r^{2} \cdot t \\
& =\frac{1}{3} \cdot 3,19 \cdot 7 \cdot 3,10 \\
& =99,2\end{aligned}$ & $\begin{array}{l}\text { - Differentiating } \\
\text { the cones, the big } \\
\text { and small ones } \\
\text { - Calculating } \\
\text { the height of the } \\
\text { small cone }\end{array}$ & $\begin{array}{l}\text { obtained comparisons } \\
\frac{\mathbf{1}}{\mathbf{3}}=\frac{\boldsymbol{x}+\mathbf{1 0}}{\mathbf{1 4}} \\
14 \mathrm{x}-7 \mathrm{x}+70 \\
14 \mathrm{x}-7 \mathrm{x}=70 \\
7 \mathrm{x}=70 \\
X=7-/ 7=10 \\
\text { large cone height }=10+10=20\end{array}$ \\
\hline $\begin{aligned} V_{k b-k_{k}} & =847,8-99,2 \\
& =753,56\end{aligned}$ & & $\begin{array}{l}\mathrm{V}=\mathrm{V}_{\text {whole cone }}-\mathrm{V}_{\text {little cone }} \\
=\frac{\mathbf{1}}{\mathbf{3}} \times 3,14 \times 14^{2} \times 20-\frac{\mathbf{1}}{\mathbf{3}} \times 3,14 \\
\times 7^{2} \times 10 \\
=3,14 \times 1.306,67-3,14 \times 163,33 \\
=4.102,94-514,86 \\
=3.590,08\end{array}$ \\
\hline
\end{tabular}

The procedure taken by $\mathrm{C} 1$ was correct. It began with using a conic concept, but the student did not acquire the concept really well. Additionally, the finding was quite blatant, especially when the student tried to find out the height of the big and small cones. The interview result with $\mathrm{C} 1$ is presented in the following excerpt.

$R \quad$ : Before finding out the final volumes of the big and small cones, do you think there is another thing needing calculation?

C1 : None.

$R \quad$ : How will you determine the elements of the big and small cones?

C1: For the big cone, the $\pi$ is 3.14, the radius is 9, and the height is 10. And, for the small cone, the $\pi$ is 3.14, the radius is 3 , and the height is 10 .

The finding has shown that the actual development level acquired by $\mathrm{C} 1$ remained at being unable to answer the question independently since the student could not solve the given problem using the correct concept and procedure. After getting the information related to $\mathrm{C} 1$ 's actual development level, the researchers used scaffolding to help the student, especially in differentiating necessary elements, the big and small cones, as well as in operating proper calculation to find out the height of the small cone. 
Referring to the answer given, the researchers gave scaffolding treatment by providing the student with an illustration of a cone on a piece of HVS paper. The paper was cut horizontally and formed like a cone to answer the second question. Then, the student was to differentiate and understand the elements that appeared on the big and small cones through Q\&A session. The student calculated the volume of the small cone using the Pythagorean Theorem. Unexpectedly, such a way remained ineffective to get the correct answer. Therefore, the researchers gave further scaffolding.

The next scaffolding was to draw a right triangle inside of the cone and to explain the concept of congruency to the student. After the student comprehended the congruency principles, the student was able to answer the question well. The student, further, was instructed to answer the second question. Based on the answer to the second question, the student's potential development level was obviously identifiable. After the scaffolding treatment, the student could answer the question based on the necessary concept and procedure.

Table 4

C2's answer

\begin{tabular}{|c|c|c|c|}
\hline $\begin{array}{l}\text { Actual Development } \\
\text { Level }\end{array}$ & Scaffolding & \multicolumn{2}{|c|}{$\begin{array}{c}\text { Potential Development Level with } \\
\text { Different Question }\end{array}$} \\
\hline No answer was given. & $\begin{array}{l}\text { - Understanding } \\
\text { the question } \\
\text { - Calculating the } \\
\text { height of the small } \\
\text { cone }\end{array}$ & $\begin{array}{c}\frac{9}{3}=\frac{10+x}{x} \\
9 x=3(10+x) \\
9 x=30+3 x \\
9 x-3 x=30 \\
6 x=30 \\
x=5\end{array}$ & $\begin{aligned} V & =\frac{1}{3} \cdot \pi \cdot r^{2} \cdot t \\
& =\frac{1}{3} \cdot 3 \cdot 14 \cdot 9 \cdot 9 \cdot(10+x) \\
& =3 \cdot 14 \cdot 27 \cdot 15 \\
& =3 \cdot 14 \cdot 405 \\
& =127 \cdot 7 \\
V & =\frac{1}{3} \cdot \pi \cdot r^{2} \cdot t \\
& =\frac{1}{3} \cdot 3 \cdot 14 \cdot 3 \cdot 3 \cdot 5 \\
& =\frac{1}{3} \cdot 3 \cdot 14 \cdot 9 \cdot 5 \\
& =\frac{1}{3} \cdot 3 \cdot 14,45 \\
& =47,1 \\
V & -V_{k K}=1271,7-47,1 \\
& =1224,6\end{aligned}$ \\
\hline
\end{tabular}

As seen in Table 4, C2 could not give any answer to the question. Extremely, the student could not understand the question well, with the answer sheet remaining blank. Further, the finding was supported by the interview with $\mathrm{C} 2$ presented below.

\section{C2 : Excuse me. I don't get the point of this question.}

Then, the student was interviewed to testify the validity of the student's confession. 


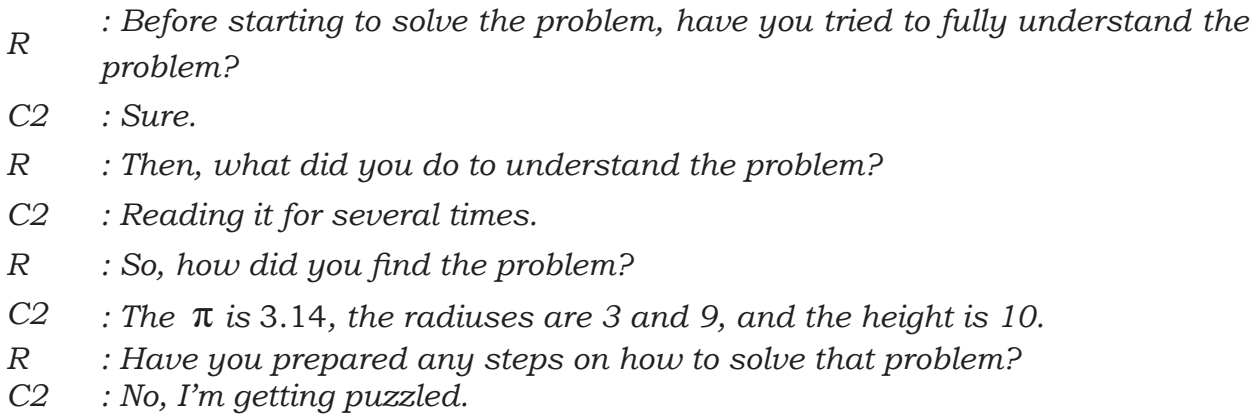

Based on the interview result, C2's actual development level was limited to being unable to answer the question independently. In other words, C2 was in need of scaffolding treatment similar to $\mathrm{C} 1$. The only difference was remarked by how $\mathrm{C} 2$ was helped to understand the question prior to finding out the height of the small cone. Practically, the first step to do was helping C2 find out the information and possible problem on the question through Q\&A session. Then, C2 was encouraged to imagine a real shape of a 'bucket', with a cone cut horizontally inside. To make it concrete, the cone was drawn on a piece of HVS paper. Using scissors, the paper was cut horizontally. Through Q\&A session, supportive elements, the small and big cones, were made explicit. Unlike C1, C2 needed extra explanation on how the calculation was begun to find out the volume of the bucket.

Confusion was much apparent when C2 started to calculate the height of the small cone. As a consequence, the researchers helped the student by explaining the concept of congruency based on the right triangle detected in the cone. After doing so, C2 could get the answer related to the height of the cone and answer the question. Based on the student's answer on the second question after the scaffolding treatment, C2's potential development was that the student could answer the question by referring to the essential concept and procedure required.

\section{Discussion}

Based on the description of the answers of the six students, there are several aspects needing exploration, especially with reference to the contiguity between the interview results and the students' answers. In fact, all of the students did not make any review on the procedures they took to answer the questions. As a consequence, the absence of reviewing stage had resulted in fallacy of calculation, especially on integer's multiplication, which was in line with the finding of this research. 
The actual development levels of the students were different. The high-achievers were exceedingly capable of answering all questions based on the necessary concepts and procedures. Meanwhile, the average- and low-achievers were able to answer the questions partially, yet not effectively, despite using the necessary concepts and procedures. In sum, the more competent the students, the higher their actual development level would be. Such a conclusion was drawn based on the students' competence in solving the problems independently, which was parallel with the finding of this research.

With reference to the diversity of the students' actual competences, scaffolding was applied in different ways. Generally, scaffolding is contingent or identical with proximity, which denotes that teachers' assistances should fit students' performance level, both through a single or multiple treatments [20]. Based on the observation results, scaffolding was only given to the averageand low-achievers. Scaffolding was applied based on the level 2 proposed by the theory [9], consisting of reviewing, restructuring and explaining. The average-achievers needed reviewing and restructuring; whilst the low-achievers required explaining in addition to reviewing and restructuring. In the level 2, scaffolding was given to the students through direct interaction since it was believed that verbal scaffolding along with interactive conversation with the competent facilitators could enhance the students' ZPD [21], primarily during Q\&A session [22].

The differences in the students' potential development levels depend much on the students' actual development levels. Every student is likely to develop, from actual to potential development level, through scaffolding. For the high-achievers, their potential development level could be continued by answering questions with higher level of difficulty by utilising various possible concepts. Meanwhile, for the average- and low-achievers, their potential development level could be remarked by their ability to answer the questions based on key concepts and procedures. On the whole, scaffolding plays a significant role in developing the students' ZPD [23].

\section{Conclusion}

Based on the findings of this current research, the analysis of the students' ZPD and the scaffolding treatment required by junior high school students are described as follows: 1) The high-achievers' actual development level lied on their ability to answer the given questions based on the necessary concepts and procedures; while the average- and low-achievers' actual development levels were reflected by their ability to answer the questions partially, yet not effectively, despite using the necessary concepts and procedures; 2) The high-achievers 
were not in need of scaffolding. Conversely, scaffolding was given to the averageand low-achievers; in which reviewing and restructuring procedures were given to the former, while reviewing, restructuring, and explaining were given to the latter. The potential development level of the high-achievers could be continued by performing other tasks or answering other questions with higher level of difficulty by utilising varying concepts. On the other hand, the average- and lowachievers' potential development level could be shown by their ability to answer the questions using proper concepts and procedures.

\section{Implications}

Referring to the results of the research on the students' ZPD and scaffolding treatment required by the junior high school students to solve mathematical problems, it is suggested that teachers be so heedful about their students' ZPD and thus more appropriate scaffolding treatments can be applied. In addition, teachers are strongly recommended to do self-training in scaffolding and to keep instructing their students to review their answers several times to avoid fallacy of operations. Besides, teachers should prepare their students to be good problemsolvers through exposing them to various exercises. For further researchers, it is highly expected that more relevant research is required to be conducted from different viewpoints, i.e. investigating the effectiveness of scaffolding.

\section{References}

1. NCTM. Principles and standards for school mathematics. Reston: The National Council of Teacher Mathematics, Inc; 2000. 392 p.

2. Shabani K., Khatib M., Ebadi S. Vygotsky's Zone of Proximal Development: Instructional implications and teachers professional development. English Language Teaching. 2010; 3 (4): 237-248.

3. Hardjito D. The use of scaffolding approach to enhance students engagement in learning structural analysis. International Education Studies. 2010; 3 (1): 130-135.

4. Reilly R. C., Mitchell S. N. The clash of the paradigms: Tracking, cooperative learning, and the demolition of the zone of proximal development. Alberta Journal of Educational Research. 2010; 56 (4): 419-435.

5. Siyepu S. The zone of proximal development in the learning of mathematics. South African Journal of Education. 2013; 33 (2): 1-13.

6. Ardana I. M., Ariawan I. P. W., Divayana D. G. H. Measuring the effectiveness of BLCS Model (Bruner, local culture, scaffolding) in mathematics teaching by using expert system-based CSE-UCLA. International Journal of Education and Management Engineering. 2017; 4 (7): 1-12.

7. Bikmaz F. H., Çelebi Ö., Ata A., Özer E., Soyak Ö., Reçber H. Scaffolding strategies applied by student teachers to teach mathematics. The International Journal of Research in Teacher Education. 2010; 1 (1): 25-36.

8. Pfister M., Opitz E. M., Pauli C. Scaffolding for mathematics teaching in inclusive primary classrooms: A video study. ZDM-Mathematics Education. 2015; 47 (7): 1079-1092. 
9. Anghileri J. Scaffolding practices that enhance mathematics learning. Journal of Mathematics Teacher Education. 2006; 9: 33-52.

10. Waiyakoon S., Khlaisang J., Koraneekij P. Development of an instructional learning object design model for tablets using game-based learning with scaffolding to enhance mathematical concepts for mathematic learning disability students. Procedia - Social and Behavioral Sciences. 2015; 174: 1489-1496.

11. Paruntu P. E., Sukestiyarno Y. L., Priyono A., Prasetyo B. Analysis of mathematical communication ability and curiosity through project based learning models with scaffolding. Unnes Journal of Mathematics Education Research. 2018; 7 (1): 26-34.

12. Smit J., van Eerde H. A. A., Bakker A. A conceptualisation of whole-class scaffolding. British Educational Research Journal. 2013; 39 (5): 817-834.

13. Rahman B., Abdurrahman A., Kadaryanto B., Rusminto N. E. Teacher-based scaffolding as a teacher professional development program in Indonesia. Australian Journal of Teacher Education. 2015; 40 (11): 66-78.

14. van de Pol J., Elbers E. Learning , culture and social interaction scaffolding student learning: A micro-analysis of teacher - student interaction. Learning, Culture and Social Interaction. 2013; 2 (1): 32-41.

15. Tarim K., Öktem S. P. Mathematical word-problems that require realistic answer. Cukurova University Faculty of Education Journal. 2016; 43 (2): 19-38.

16. Zamzam K. F., Patricia F. A. Error analysis of newman to solve the geometry problem in terms of cognitive style. Advances in Social Science, Education and Humanities Research. 2018; 160: 24-27.

17. Orrantia J., Muñez D., Vicente S., Verschaffel L., Rosales J. Processing of situational information in story problem texts. An analysis from on-line measures. The Spanish Journal of Psychology. 2014; 17 (8): 1-14.

18. Nasution F. Y. Misconception's analysis of students junior high school in solving algebra problems term of field independent and field dependent cognitive styles. In: Proceedings of the International Conference on Mathematical Analysis, Its Applications and Learning 2018; 2018 Sep 15; Yogyakarta. Ed. by B. Utomo. Yogyakarta: Sanata Dharma University Press; 2018. p. 1-6.

19. Polya G. How to solve it a new aspect of mathematical method. $2^{\text {nd }}$ ed. New Jersey: Princeton University Press; 1973. 253 p.

20. van de Pol J., Volman M., Beishuizen J. Scaffolding in Teacher - Student Interaction: A decade of research. Educational Psychology Review. 2010; 22: 271-296.

21. Wass R., Harland T., Mercer A. Scaffolding critical thinking in the zone of proximal development. Higher Education Research \& Development. 2011; 30 (3): 317-328.

22. Schwieter J. W. Developing second language: Writing through scaffolding in the ZPD: A magazine project for an authentic audience. Journal of College Teaching \& Learning. 2010; 7 (10): 31-46.

23. Shooshtari Z. G., Mir F. ZPD, tutor; peer scaffolding: Sociocultural theory in writing strategies application. Procedia - Social and Behavioral Sciences. 2014; 98: 1771-1776.

\section{Information about the authors:}

Dwi Priyo Utomo - M. Sci. (Mathematics), Principal Lecturer and Secretary of the Research, Department of Mathematics Education, Faculty of Teacher Training and Education, University of Muhammadiyah; ORCID 0000-0002-8284-5159; Malang, Indonesia. E-mail: dwipriyoutomo2021@gmail.com; dwi_priyo@umm.ac.id 
Teguh Santoso - M. Sci. (Mathematics), Lecturer, Department of Mathematics Education, Faculty of Teacher Training and Education, University of Muhammadiyah, Malang, Indonesia. E-mail: teguhsantosoumm@gmail.com

Conflict of interest statement. The authors declare that there is no conflict of interest.

Received 03.05.2021; revised 28.09.2021; accepted for publication 06.10.2021.

The authors have read and approved the final manuscript.

\section{Ннформаиия об авторах:}

Утомо Дви Приё - магистр (математика), старший преподаватель и секретарь по исследованиям кафедры математического образования педагогического факультета Университета Мухаммадии; ORCID 0000-0002-8284-5159; Маланг, Индонезия. E-mail: dwipriyoutomo2021@gmail.com; dwi_priyo@umm.ac.id

Сантосо Тегух - магистр (математика), преподаватель кафедры математического образования педагогического факультета Университета Мухаммадии, Маланг, Индонезия. E-mail: teguhsantosoumm@gmail.com

информация о конфликте интересов. Авторы заявцяют об отсутствии конфмикта интересов.

Статья поступима в редакцию 03.05.2021; поступима после рецензирования 28.09.2021; принята к публикации 06.10.2021.

Авторы прочитали и одобрили окончательный вариант рукописи. 